$\mathrm{P}$

азработка и оценка эффективности комплекса профилактических мероприятий по предупреждению распространения гонококковой инфекции в Архангельской области

А.А. Кубанов ${ }^{1}$, К.В. Барышков², И.Д. Приб², Н.В. Фригоำ

1 ФГБУ «Государственный научный центр дерматовенерологии и косметологии» Минздрава России 107076, Москва, ул. Короленко, д. 3, стр. 6

2 ГБУЗ АО «Архангельский клинический кожно-венерологический диспансер» 163045, Архангельск, проезд Сибиряковцев, д. 2, корп. 1

Цель исследования. Оценить эффрективность разработанного в 2011-2012 гг. комплекса профилактических мероприятий по предупреждению распространения гонококковой инфекции в Архангельской области на основании изучения динамики заболеваемости гонококковой инфекцией на территории области в 2011-2013 гг. Материал и методы. Проанализированы статистические данные о заболеваемости гонококковой инфекцией на территории Архангельской области. Для оценки эффрективности разработанного комплекса мероприятий по предупреждению распространения гонококковой инфекции и других инфекций, передаваемых половым путем (ИППП), в Архангельской области рассчитывался темп изменения показателей заболеваемости.

Результаты. Комплекс профилактических мероприятий по предупреждению распространения гонококковой инфекции в Архангельской области был разработан в 2011 г. и внедрен в практическое здравоохранение в 2012 г. По данным 2012 г., в Архангельской области был отмечен рост на 49,1\% заболеваемости гонококковой инфекцией в сравнении с 2011 г., что могло быть обусловлено совершенствованием регистрации случаев гонококковой инсекции в ведомственных и частных медицинских организациях и оптимизацией выявления инсекции методами культурального исследования и полимеразной ценной реакции, в особенности у женщин. В 2013 г. в абсолютном большинстве (в 20 районах и городах - 76,9\% территорий) муниципальных образований Архангельской области отмечено снижение заболеваемости гонококковой инфекцией в сравнении с 2012 г. (в 2012 г. — 85,3 случая на 100000 населения, в 2013 г. — 68,6), в том числе среди подростков (с 76,9 на 100000 населения в 2012 г. до 52,9 — в 2013 г.).

Выводы. Внедрение в практическое здравоохранение разработанного комплекса профилактических мероприятий по предупреждению распространения гонококковой инфекции и других ИППП в Архангельской области позволило к 2013 г. существенно снизить уровень заболеваемости гонококковой инсекцией на территории области. Полученные данные позволяют положительно оценить эфффективность разработанных мероприятий и отметить их вклад в снижение уровня заболеваемости гонококковой инорекцией.

Ключевые слова: гонококковая инфекция, $\boldsymbol{N}$. gonorrhoeae, профилактика, эпидемиология.

Контактная информация: kvbar@yandex.ru. Вестник дерматологии и венерологии 2014; (2): 16—25. 


\title{
Development of a complex of preventive measures and their assessment to prevent the propagation of gonococcal infection in the arkhangelsk region
}

\author{
A.A. Kubanov¹, K.V. Baryshkov², I.D. Prib², N.V. Frigo ${ }^{1}$ \\ ${ }^{1}$ State Research Center of Dermatovenereology and Cosmetology, Ministry of Healthcare of the Russian Federation \\ Korolenko str., 3, bldg 6, Moscow, 107076, Russia
}

${ }^{2}$ Arkhangelsk Clinical Dermatovenerology Dispensary

Sibiryakovtsev proyezd, 2, bldg 1, Arkhangelsk, 163045, Russia

Goal of the study. To assess the efficacy of a complex of preventive measures developed in 2011-2012 for preventing the propagation of gonococcal infection in the Arkhangelsk region based on a study of the gonococcal infection morbidity dynamics in the territory of the region in 2011-2013.

Study materials and methods: the authors analyzed statistics on the gonococcal infection morbidity in the territory of the

Arkhangelsk region. To assess the efficacy of the complex of measures developed to prevent the propagation of gonococcal infection and other STDs in the Arkhangelsk region, the morbidity dynamics rate was calculated.

Results. A complex of preventive measures for preventing the propagation of gonococcal infection in the Arkhangelsk region was developed in 2011 and was put to practical use in 2012. In 2012, the gonococcal infection morbidity rate grew in the Arkhangelsk region by $49.1 \%$ vs. 2011. Such a growth can be explained by the improved procedures for recording cases of gonococcal infection used in departmental and private medical organizations as well as optimization of the infection diagnostics methods including cultural tests and PCR, in particular, in women. In 2013, the incidence of gonococcal infection fell down as compared to 2012 (85.3 cases per 100,000 people in 2012 and 68.6 cases in 2013) including among teenagers (76.9 cases per 100,000 people in 2012 and 52.9 cases in 2013) in most municipal districts of the Arkhangelsk region (in 20 districts and towns, or $76.9 \%$ of the territory).

Conclusions. Practical implementation of the complex of preventive measures developed to prevent the propagation of gonococcal infection and other STDs in the Arkhangelsk region substantially reduced the morbidity of gonococcal infection in the territory of the region. The collected data are sufficient to give a positive assessment of the developed measures and emphasize their contribution to the reduction of the morbidity of gonococcal infection.

Key words: gonococcal infection, $N$. gonorrhoeae, prevention, epidemiology. 
Гонококковая инфекция - социально значимая инфекция, передаваемая половым путем (ИППП). Несмотря на наблюдаемую в последние годы тенденцию к снижению, заболеваемость гонококковой инфекцией в Российской Федерации продолжает оставаться высокой. В 2012 г. уровень заболеваемости гонококковой инфекцией в Российской Федерации составил 36,4 на 100000 населения, что существенно выше, чем в развитых странах Европы $[1,2]$.

Высокий эпидемический уровень распространения гонококковой инфекции обусловливает необходимость поиска фракторов, влияющих на распространение заболевания на уровне отдельных субъектов Российской Федерации, и путей совершенствования контроля над распространением заболевания. Основанием для разработки профилактических мероприятий, направленных на предупреждение распространения гонококковой инфекции на отдельных территориях, могут стать как знания об эпидемиологических факторах риска, так и результаты исследований штаммов возбудителя гонококковой инфекции N. gonorrhoeae, полученных с использованием методов молекулярной эпидемиологии.

С 2006 г. ГБУЗ АО «Архангельский клинический кожно-венерологический диспансер» (АККВД) под руководством ФГБУ «Государственный научный центр дерматовенерологии и косметологии» Минздрава России (Москва) проводит исследование, направленное на совершенствование методов контроля над распространением гонококковой инфекции на территории Архангельской области и разработку комплекса профрилактических мероприятий по предупреждению распространения гонококковой инфекции в Архангельской области на основании результатов изучения эпидемиологических фракторов риска, показателей чувствительности штаммов $N$. gonorrhoeae к антимикробным препаратам (АМП) и молекулярно-генетических особенностей штаммов N. gonorrhoeae.

В рамках проводимого исследования изучена заболеваемость гонококковой инфекцией в Архангельской области за период 2001-2011 гг.; проведен анализ гендерного и возрастного распределения, социальной принадлежности, уровня образования и семейного положения больных. В районах области с различным уровнем заболеваемости гонококковой инфекцией в сравнительном аспекте изучены показатели плотности населения, численности дерматовенерологов, «профиль» территории (сельскохозяйственная, промышленная, по видам промышленности); качество транспортного сообщения [3]. В результате проведенных исследований отмечено, что Архангельская область относится к территориям, неблагополучным по заболеваемости гонококковой инфекцией: уровень заболеваемости гонококковой инфекцией в Архангельской области на протяжении 10 лет наблюдения (с 2001 по 2011 г.) значительно превышал уровень за- болеваемости в РФ и Северо-Западном фредеральном округе в целом как среди взрослого населения, так и среди подростков 15-17 лет, которые являются значимой группой риска в отношении заражения гонококковой инфекцией, что подтверждается высоким уровнем заболеваемости гонококковой инорекцией среди данного контингента обследованных на протяжении всех лет наблюдения (с 2001 по 2011 г.).

При изучении эпидемиологических фракторов, способствующих распространению гонококковой инфекции на территории Архангельской области, выявлено, что группой риска в отношении заражения и распространения гонококковой инфекции в Архангельской области являются также молодые мужчины в возрасте 20-29 лет, имеющие среднее образование, не занятые в сфере общественного производства, служащие или работающие на промышленных предприятиях, не состоящие в браке, практикующие частые, порой случайные незащищенные половые контакты с женщинами.

Также установлено, что фрактором риска в отношении заражения гонококковой инфекцией и ее распространения в Архангельской области может являться проживание в крупных городах области с развитой тяжелой (машиностроение, судостроение), нестедобывающей и нефтеперерабатывающей промышленностью, а также транспортом (в особенности, морским и речным), где в основном трудятся мужчины молодого возраста и отмечается высокая миграционная активность населения (туризм, командировки, трудовая миграция).

С целью научного обоснования стратегии антимикробной терапии гонококковой инфекции на территории Архангельской области изучены показатели чувствительности штаммов N. gonorrhoeae, полученных от больных гонококковой инфекцией на территории Архангельской области в 2006-2011 гг., к АМП. Проведены молекулярные исследования штаммов N. gonorrhoeae [4]. В результате исследований было установлено, что на территории Архангельской области отмечается высокий процент штаммов N. gonorrhoeae, не чувствительных к пенициллину, тетрациклину и ципрофлоксацину, регистрируется достаточно высокий процент штаммов $N$. gonorrhoeae, не чувствительных к спектиномицину и азитромицину, существенно превышающий уровень, рекомендуемый ВОЗ для назначения этих АМП [5], что позволяет расценивать ситуацию по антибиотикорезистентности N. gonorrhoeae в Архангельской области как неблагополучную. Результаты исследования позволили заключить, что препаратом выбора для лечения гонококковой инфекции на территории области остается цефтриаксон, к которому сохраняют чувствительность все штаммы $N$. gonorrhoeae, полученные от больных гонококковой инфекцией на территории области. Однако с учетом появления признаков формирующейся 
устойчивости штаммов $N$. gonorrhoeae к данному АМП на территории области необходима разработка дополнительной системы мер, направленных на предотвращение распространения гонококковой инфекции и резистентных к цефтриаксону штаммов $N$. gonorrhoeae.

Методами молекулярного типирования и филогенетического анализа установлена значительная гетерогенность выборки штаммов N. gonorrhoeae, циркулирующих на территории Архангельской области, и высокая скорость их генетической изменчивости; выявлены сиквенс-типы штаммов N. gonorrhoeae, общие с таковыми на других территориях РФ и в других странах мира, что указывает на пути их возможного распространения; также зарегистрированы штаммы N. gonorrhoeae, уникальные для Архангельской области.

В результате проведенных молекулярно-генетических исследований показана возможность использования молекулярных методов (полимеразной цепной реакции - ПЦР и секвенирования) для индивидуальной идентификации источников заражения и половых партнеров больных гонококковой инфекцией, а также для отслеживания распространения мультирезистенных штаммов N. gonorrhoeae, определения тактики терапии пациентов, инфицированных мультирезистентными штаммами, и осуществления эпидемиологического мониторинга.
Полученные результаты послужили основанием для разработки комплекса профилактических мероприятий по предупреждению распространения гонококковой инфекции и других ИППП в Архангельской области.

Цель настоящего исследования: оценить эфрфективность разработанного комплекса профилактических мероприятий по предупреждению распространения гонококковой инфекции в Архангельской области на основании изучения динамики заболеваемости.

\section{Материал и методы}

В качестве материалов исследования использованы данные государственной статистики о заболеваемости ИППП на территории РФ, а также статистические данные о заболеваемости гонококковой инфекцией и другими ИППП на территории Архангельской области.

Для оценки эффективности разработанного комплекса мероприятий по предупреждению распространения гонококковой инфекции в Архангельской области применялся расчет темпа изменения показателей заболеваемости. Темп изменения показателей заболеваемости рассчитывали как относительную разницу заболеваемости изучаемого года к заболеваемости предшествующего года (лет) по формуле $\begin{aligned} & \text { Темп роста (снижения) } \\ & \begin{array}{l}\text { показателя } \\ \text { заболеваемости }\end{array}\end{aligned}=\frac{\begin{array}{c}\text { Показатель заболеваемости изучаемого года }- \\ \text { Показатель заболеваемости предшествующего года }\end{array} 100 .}{\text { Покатель заболеваемости предшествующего года }}$

\section{Результаты и обсуждение}

В период 2009-2011 гг. в Архангельской области действовала целевая региональная программа, направленная на предупреждение распространения ИППП «Предупреждение и борьба с социально значимыми заболеваниями на 2009-2011 гг.» (Постановление Администрации Архангельской области от 26 августа 2008 г. № 188-па/27).

С учетом результатов настоящего исследования была разработана и в 2012 г. принята и внедрена в практическое здравоохранение ведомственная целевая программа «Приоритетные социально значимые мероприятия в сорере здравоохранения на 2012-2014 гг.» (Распоряжение Министерства здравоохранения Архангельской области от 24 февраля 2012 г. № 193-ро).

Первоочередными задачами программы явились:

внедрение современных методов профилактики, диагностики и лечения социально значимых заболеваний;

повышение доступности, эфффективности и качества оказания медицинской помощи населению области; улучшение материально-технической базы учреждений здравоохранения;

снижение заболеваемости населения социально значимыми заболеваниями (в том числе гонококковой инфекцией и другими ИППП).

На основании результатов изучения эпидемиологических факторов риска, показателей чувствительности штаммов N. gonorrhoeae к АМП и их молекулярно-генетических особенностей, а также рекомендаций, изложенных в принятом ВОЗ документе «Глобальная стратегия профилактики инфекций, передаваемых половым путем, и борьбы с ними, 2006-2015 гг.» (Всемирная организация здравоохранения, 2007) [6], был разработан и включен в программу Комплекс профилактических мероприятий по предупреждению распространения гонококковой инфекции и других ИППП в Архангельской области.

Комплекс профилактических мероприятий в отношении распространения гонококковой инфекции и других ИППП на территории Архангельской области включал следующие мероприятия.

1. Расширение перечня контингентов, подлежащих эпидемиологическому наблюдению, за счет мужчин 
трудоспособного возраста (приоритетный возраст 20-29 лет), не работающих, либо служащих, либо занятых в сорере промышленного производства, речного и морского транспорта.

Для данного контингента лиц в регионах Архангельской области с высоким уровнем заболеваемости (в Архангельске, Северодвинске, Котласе и др.) были:

совместно с администрациями муниципальных образований региона разработаны планы мероприятий, направленных на предупреждение распространения ИППП;

пазработаны памятки и мультимедийные программы, освещающие пути инфицирования ИППП, их последствия, фракторы риска инфицирования и методы профилактики ИППП;

- проведены лекции и тренинги по вопросам профилактики ИППП и пропаганды безопасного полового поведения в формате «вопрос - ответ»;

в кабинетах приема врачей-дерматовенерологов, кабинетах профилактических осмотров на предприятиях промышленности (в особенности - военно-промышленного комплекса), в морских и речных портах были выделены специальные часы приема с целью просвещения и консультирования по способам предотвращения или снижения риска заражения гонококковой инфекцией и другими ИППП, включая ВИЧ.

2. Совершенствование контроля над регистрацией случаев заболеваний (и в частности - гонококковой инфекции) в учреждениях здравоохранения, в том числе в ведомственных медицинских организациях и в медицинских организациях частных форм собственности. К ведомственным организациям относятся медицинские организации МВД, РЖД, УФСИН, ФМБА (военно-промышленный комплекс, морской и речной транспорт). Медицинские организации частных форм собственности находятся в основном в городах: Архангельске, Северодвинске, Котласе. В рамках проведения областных итоговых конференций дерматовенерологической службы ежегодно рассматривались вопросы регистрации заболеваний, статистики.

3. Проведение профилактических мероприятий среди большого скопления лиц молодого возраста, в местах досуга и отдыха молодежи (кинотеатры, кафе, ночные клубы, транспорт, крупные торгово-развлекательные центры, средние специальные учебные заведения, вузы и др.), в женских консультациях, в центрах репродуктивного здоровья, центрах профилактики и лечения ВИЧ-инфекции, наркологических диспансерах:

- распространение подготовленной специальной литературы информационно-образовательного характера по вопросам профилактики ИППП и пропаганды безопасного полового поведения; литература была распространена волонтерами среди лиц молодого возраста; всего за период 2011-2013 гг. было издано и распространено более 7000 экземпляров брошюр, листовок, памяток;

размещение на остановках общественного транспорта разработанных информационных материалов: листовок и рекламных щитов, содержащих информацию о путях передачи ИППП и способах предотвращения или снижения риска заражения гонококковой инфекцией и другими ИППП, включая ВИЧ, необходимости безопасного секса путем использования средств барьерной контрацепции.

4. Активизация работы подросткового центра профрилактики и лечения ИППП «Ювентус-ІІ», действующего на территории области.

В 2012-2013 гг. была в значительной степени активизирована деятельность подросткового центра «Ювентус-ІІ». Диагностическая и лечебная помощь несовершеннолетним оказывалась дерматовенерологом, гинекологом и урологом; проводилось консультирование подростков по вопросам профилактики ИППП, особенностям полового поведения, профилактики нежелательной беременности. Психологами и социальными педагогами осуществлялась диагностика, коррекция и реабилитация невротических состояний у подростков.

Всего в 2012 и 2013 гг. обследование по поводу ИППП в подростковом центре «Ювентус-ІІ» получили 5870 детей (в 2012 г. 2645 детей, в 2013 г. - 3225).

За 2013 г. дерматовенерологом в центре «Ювентус-ІІ» было обследовано 3195 человек, в том числе по поводу заболеваний - 2471 (первичных 662, повторных 1809), по поводу профилактических осмотров - 724, из них первичных 357. Нагрузка врача-дерматовенеролога в 2013 г. составила 3,4 человека в час. Психологами центра были проведены 742 индивидуальные консультации и профилактические беседы.

В 2013 г. отмечено увеличение количества посещений дерматовенеролога по поводу заболеваний и профрилактических осмотров, что связано с появлением в центре постоянно работающего заведующего отделением.

Среди обследованных в центре детей и подростков в 2013 г. выявлено 193 новых случая ИППП (в 2012 г. - 112 случаев). Выявлено 14 случаев гонореи среди детей и подростков (в 2011 г. - 10, В 2012 г. - 17). В 2013 г. зарегистрировано на 3 случая гонореи меньше, чем в 2012 г. Обследование несовершеннолетних на наличие гонококковой инфекции проводилось культуральным методом и методом ПЦР. Для идентификации других возбудителей ИППП применялись современные методы диагностики: ПЦР, культуральный метод, метод иммуноферментного анализа.

В подростковом центре «Ювентус-ІІ» с 2012 г. психологом проводится цикл занятий, направленных на формирование культуры полового общения и по- 
зитивного отношения к здоровому образу жизни, для подростков образовательных и социально-реабилитационных учреждений по темам программы «Формирование культуры полового общения в подростковоюношеском возрасте». Темы занятий:

1) «Сексуальность и культура» (культура полового общения в современном обществе);

2) «Прекрасная пора взросления» (половое самосознание, половое поведение, половая ориентация);

3) «Будущие женщины и мужчины, мамы и папы» (психологические особенности женщины и мужчины; женственность и мужественность);

4) «Мудрость человеческого общения» (психологические механизмы общения, предупреждение и разрешение конфрликтов);

5) “Слагаемые счастливой жизни» (особенности развития репродуктивной системы, современные методы контрацепции);

6) «Чтобы не случилась беда» (профилактика инфрекций, передаваемых половым путем);

7) «Семья - школа: формирование потребности любить и быть любимым» (круглый стол: значение, слагаемые и особенности любви);

8) тренинги отработки навыков эффрективного общения с целью профилактики негативных явлений социального характера у молодежи.

Психологом проведено 234 групповых занятия (семинары, беседы, тренинги) с подростками в образовательных учреждениях города по темам программы «Формирование культуры полового общения в подростково-юношеском возрасте». Занятия включают в себя не только первичную профилактику, но и вопросы формирования культуры полового общения.

В 2013 г. в сравнении с предыдущими годами увеличилось количество образовательных учреждений, сотрудничающих с центром (заключено 25 соглашений).

Всего за 2012-2013 гг. проведено 441 групповое занятие (семинары, беседы, тренинги, видеолектории) по вопросам профилактики ИППП, культуры полового общения и охраны репродуктивного здоровья на базе центра (214 занятий) и в образовательных учреждениях Архангельска и области (227 занятий).

Проведено 1670 индивидуальных консультаций и профилактических бесед психолога по вопросам межличностных отношений, последствий раннего начала половой жизни, преодоления страха обращения к врачу.

Сотрудниками центра в течение года распространялись брошюры, буклеты, листовки по вопросам профиллактики ИППП, ВИЧ/СПИДа.

Проведено 14 родительских собраний в учебных заведениях Архангельска по вопросам воспитания культуры полового общения, особенностям взросления и становления сексуальности в подростково-юношеском возрасте.
Проведено 25 медико-педагогических совещаний по вопросам работы педагогов с подростками по формированию полоролевого поведения.

В 2012-2013 гг. осуществлялась межведомственная работа: участие специалистов центра в совместных мероприятиях по профилактике ИППП, ВИЧ/ СПИДа, наркомании, ранней беременности и другим негативным явлениям социального характера в молодежной среде с Центром медицинской профилактики, кафедрой социального здоровья ИППК РО, Центром борьбы со СПИДом и инфекционными заболеваниями, Центром защиты прав несовершеннолетних «Душа», заместителями директоров по охране жизни и здоровья детей общеобразовательных школ Архангельска, Центром медико-социальной и психологопедагогической помощи детям и подросткам «Леда», Центром психолого-педагогической реабилитации и коррекции «Надежда», с учреждениями, оказывающими социальную поддержку беспризорным детям и детям, оставшимся без попечения родителей (Центр защиты прав несовершеннолетних, Цигломенский детский дом, детский дом № 2), Центром временного содержания несовершеннолетних правонарушителей, школой-интернатом «Архангельский морской кадетский корпус».

Психологом центра проводились обучающие семинары с элементами тренинга для специалистов, работающих с детьми и подростками, направленные на освоение интерактивных методов профилактической работы. Семинары проведены в Институте переподготовки и повышения квалификации работников образования, в Центре психолого-педагогической и медико-социальной помощи детям и подросткам «Леда», в Центре медицинской профилактики, а также на базе ГБУЗ АО «АККВД».

С целью повышения уровня информированности и предупреждения заболеваний социального характера, по приглашению образовательных учреждений, с 2012 г. проводились беседы-презентации для родителей (14 занятий).

В рамках Российско-Норвежского проекта «Начни с себя» на протяжении 2012-2013 гг. на обучающих семинарах-тренингах велась подготовка подростков - волонтеров, учащихся образовательных учреждений городов Котласа, Коряжмы, Новодвинска, Северо-двинска. Подготовлена группа подростков волонтеров Катунинской школы Приморского района. Учитывая, что ИППП являются «болезнями поведения», главная цель в обучении волонтеров - отработка навыков эффективной коммуникации для безопасного поведения.

В связи с повышением интереса общества к проблемам молодежи и формированию здорового образа жизни, а также утверждением программы ПСЦ «Ювентус-ІІ» — «Формирование культуры полового общения в подростково-юношеском возрасте» 
увеличилось количество приглашений специалистов центра в районы Архангельской области с целью проведения семинаров с подростками, специалистами и родителями по вопросам формирования безопасного поведения и охраны репродуктивного здоровья. В течение 2013 г. семинары проведены на следующих территориях: Приморский, Мезенский, Онежский, Шенкурский, Котласский, Устьянский районы и Северодвинск.

5. Активизация работы сайта о путях и методах профилактики ИППП.

Для повышения информированности населения Архангельской области о путях и методах профилактики ИППП в 2010 г. был создан сайт http://www.aokkvd.ru/. Посетители сайта могут получить не только информацию о заболеваемости ИППП в Архангельской области, но также записаться на прием и проконсультироваться с врачом-дерматовенерологом в режиме online. В 2012 г. сайт посетило 5714 пользователей, в 2013 г. - 8760 (для сравнения: в 2011 г. - 3501).

6. Приобретение современного лабораторного оборудования.

На средства программы (на сумму 4863000 руб.) для оптимизации лабораторной диагностики ИППП, в том числе гонококковой инфекции, в 2012 г. было приобретено современное лабораторное оборудование для ГБУЗ АО «АККВД», что позволило существенно повысить качество диагностики ИППП.

7. Совершенствование доставки биологического материала от больных гонококковой инфекцией из учреждений здравоохранения Архангельской области в лабораторное отделение диспансера.

Взятие материала для культурального исследования и помещение его в транспортные среды; сокращение до 24 ч. времени доставки биологического материала из районов области в ГБУЗ АО «АККВД» в транспортной среде.

8. Проведение рациональной этиологической антимикробной терапии гонококковой инфекции.

По результатам выполненного исследования и в соответствии с Клиническими рекомендациями РОДВК 2011-2012 гг. на территории Архангельской области этиологическая антимикробная терапия гонококковой инфекции проводится цефалоспоринами III поколения (цефтриаксон, цефиксим).

9. Проведение на регулярной основе мониторинга чувствительности N. gonorrhoeae к АМП.

В крупных медицинских организациях области, оказывающих специализированную медицинскую помощь больным гонококковой инфекцией (Архангельск, Северодвинск), на регулярной основе осуществляется мониторинг чувствительности $N$. gonorrhoeae к АМП дискодиффузионным методом. Результаты мониторинга анализируются в ГБУЗ АО «АККВД».

10. Отслеживание случаев неудач лечения больных гонококковой инфекцией цефалоспоринами III поколения.
Для врачей-дерматовенерологов области, оказывающих специализированную медицинскую помощь больным гонококковой инфекцией, составлены памятки, предписывающие отслеживать и анализировать случаи неудач лечения больных гонококковой инфекцией цефалоспоринами III поколения и сообщать об этих случаях в АККВД.

11. Внедрение методов молекулярной эпидемиологии (изучение нуклеотидной последовательности вариабельных участков генов por и tbp N. gonorrhoeae методом секвенирования) для выявления источников заражения, половых партнеров и эпидемиологических путей передачи гонококковой инфекции, выявления мультирезистентных штаммов $N$. gonorrhoeae по сиквенс-типам.

В настоящее время изучение штаммов N. gonorrhoeae молекулярно-биологическими методами проводится на базе ФГБУ «Государственный научный центр дерматовенерологии и косметологии». Результаты проведенных исследований оперативно доводятся до сведения главного врача АККВД и анализируются.

АККВД планируется приобретение лабораторного оборудования, необходимого для проведения исследований с использованием методов молекулярной эпидемиологии на территории Архангельской области.

Разработанный Комплекс профрилактических мероприятий в отношении распространения гонококковой инфекции и других ИППП на территории Архангельской области был внедрен на территории области в 2012 г.

Для оценки эфффективности разработанного Комплекса мероприятий был проведен анализ динамики заболеваемости гонококковой инфекцией в Архангельской области в 2012-2013 гг.

Анализ заболеваемости показал, что в 2012 г. в целом по Архангельской области был отмечен рост на $49,1 \%$ заболеваемости гонококковой инфекцией в сравнении с 2011 г. (в 2011 г. - 57,2 случая на 100000 населения, в 2012 г. - 85,3) [7] (таблица).

Повышение уровня заболеваемости отмечалось в 13 районах области. Существенный рост заболеваемости с превышением среднероссийских показателей отмечался в относительно небольшом числе районов: в Лешуконском (рост на 5,1\%; 66,3 случая на 100000 населения), Няндомском (рост на 93,2\%, 51,2 случая на 100000 населения), Плесецком (рост на 63,9\%, 40,0 случая на 100000 населения), Приморском (рост на 81,8\%, 38 случаев на 100000 населения) районах, в городах - Архангельске (рост на 27,1\%, 129 случаев на 100000 населения), Коряжме (рост на 31,7\%, 66,5 случая на 100000 населения) и в Ненецком автономном округе (рост на 69,4\%, 165 случаев на 100000 населения). В остальных районах области уровень заболеваемости не превышал показателя, среднего по РФ (36,4 случая на 100000 населения). 
Таблица

Показатели заболеваемости гонококковой инфекцией в районах и городах Архангельской области в период 2011-2013 гг. (на 100000 населения)

\begin{tabular}{|c|c|c|c|c|c|}
\hline Субъект & 2011 г. & 2012 г. & 2013 г. & $\begin{array}{c}\text { Изменения } 2012 \text { г. } \\
\text { к } 2011 \text { г., \% }\end{array}$ & $\begin{array}{c}\text { Изменения } 2013 \text { г. } \\
\text { к } 2012 \text { г., \% }\end{array}$ \\
\hline Архангельская область & 57,2 & 85,3 & 68,6 & $+49,1 \uparrow$ & $-19,6 \downarrow$ \\
\hline Вельский & 69,6 & 66,9 & 41,4 & $-3,9$ & $-38,1$ \\
\hline Верхнетоемский & 53,1 & 30,7 & 12,8 & $-42,2$ & $-58,3$ \\
\hline Вилегодский & 18,0 & 9,2 & 0 & $-48,9$ & $-100,0$ \\
\hline Виноградовский & 60,0 & 18,4 & 6,3 & $-69,3$ & $-65,8$ \\
\hline Каргопольский & 76,3 & 76,9 & 33,3 & $+0,8 \uparrow$ & $-56,7$ \\
\hline Коношский & 15,4 & 27,8 & 20,5 & $+80,5 \uparrow$ & $-26,3$ \\
\hline Котласский & 52,7 & 38,6 & 29,4 & $-26,8$ & $-23,8$ \\
\hline Красноборский & 21,8 & 22,4 & 7,6 & $+2,8 \uparrow$ & $-65,8$ \\
\hline Ленский & 60,1 & 38,8 & 32,0 & $-35,4$ & $-17,5$ \\
\hline Лешуконский & 63,1 & 66,3 & 27,7 & $+5,1 \uparrow$ & $-58,2$ \\
\hline Мезенский & 9,7 & 29,9 & 40,9 & $+208,2 \uparrow$ & $+36,8 \uparrow$ \\
\hline Няндомский & 26,5 & 51,2 & 34,9 & $+93,2 \uparrow$ & $-31,8$ \\
\hline Онежский & 2,8 & 5,8 & 8,9 & $+107,1 \uparrow$ & $+53,4 \uparrow$ \\
\hline Пинежский & 33,5 & 3,8 & 7,9 & $-88,7$ & $+107,9 \uparrow$ \\
\hline Плесецкий & 24,4 & 40 & 28,3 & $+63,9 \uparrow$ & $-29,3$ \\
\hline Приморский & 20,9 & 38 & 19,1 & $+81,8 \uparrow$ & $-49,7$ \\
\hline Устьянский & 55,8 & 33,8 & 51,9 & $-39,4$ & $+53,6 \uparrow$ \\
\hline Холмогорский & 16,0 & 16,7 & 4,3 & $+4,4 \uparrow$ & $-74,3$ \\
\hline Шенкурский & 33,1 & 20,4 & 21,0 & $-38,4$ & $+2,9 \uparrow$ \\
\hline Архангельск & 101,5 & 129 & 102,5 & $+27,1 \uparrow$ & $-20,5$ \\
\hline Коряжма & 50,5 & 66,5 & 49,3 & $+31,7 \uparrow$ & $-25,9$ \\
\hline Котлас & 73,5 & 57,2 & 55,9 & $-22,2$ & $-2,3$ \\
\hline Новодвинск & 59,1 & 42,2 & 37,6 & $-28,6$ & $-10,9$ \\
\hline Северодвинск & 149,7 & 136,4 & 122,3 & $-8,8$ & $-10,3$ \\
\hline Ненецкий автономный округ & 97,4 & 165 & 98,2 & $+69,4 \uparrow$ & $-40,5$ \\
\hline Мирный & 33,2 & 16,3 & 19,6 & $-50,9$ & $+20,2 \uparrow$ \\
\hline
\end{tabular}

Анализ причин возрастания уровня заболеваемости населения Архангельской области гонококковой инфекцией показал, что рост заболеваемости мог быть обусловлен совершенствованием регистрации случаев гонококковой инфекции в учреждениях здравоохранения, в том числе в ведомственных и частных медицинских организациях, и улучшением качества лабораторной диагностики гонококковой инфекции за счет активного внедрения ПЦР и культурального метода исследования для диагностики гонококковой инфекции, в особенности у женщин.
Внедрение разработанного комплекса профрилактических мероприятий в практику здравоохранения Архангельской области позволило к 2013 г. значительно улучшить эпидемиологическую ситуацию по заболеваемости гонококковой инфекцией.

В 2013 г. в целом по Архангельской области было отмечено снижение заболеваемости гонококковой инфекцией в сравнении с 2012 г. на 19,6\% (в 2012 г. - 85,3 случая на 100000 населения, в 2013 г. - 68,6). Существенно снизился уровень заболеваемости гонококковой инфекцией среди 


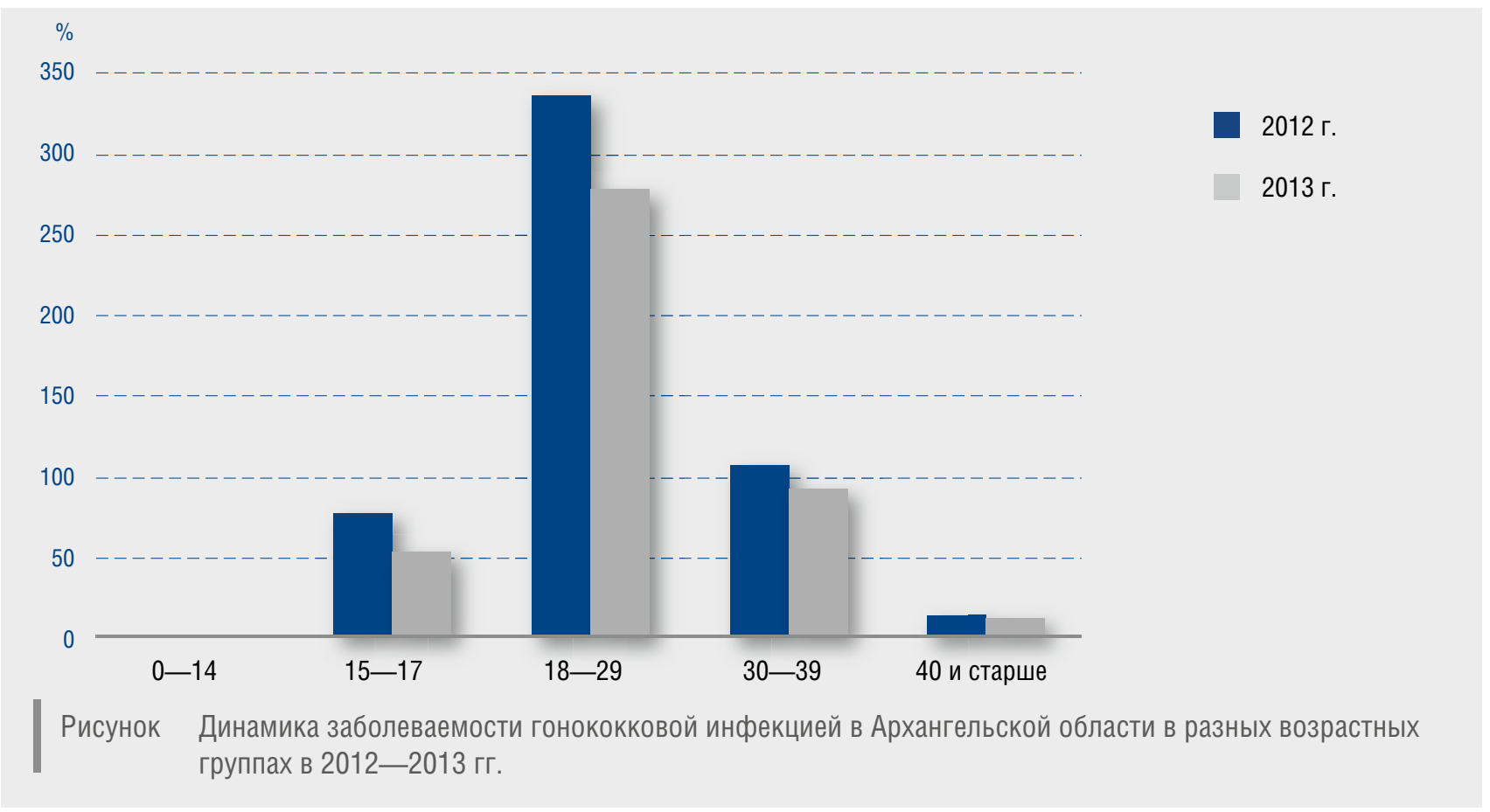

подростков (с 76,9 на 100000 населения в 2012 г. до 52,9 - в 2013 г.) (рисунок).

Примечательно, что снижение уровня заболеваемости наблюдалось в абсолютном большинстве муниципальных образований области (в 20 районах и городах - 76,9\% территорий). Наиболее значительное снижение уровня заболеваемости (на 40-100\%) отмечено в Вилегодском (на 100\%), Холмогорском (на 74,3\%), Виноградовском (на 65,8\%), Красноборском (на 65,8\%), Верхнетоемском (на 58,3\%), Лешуконском (на 58,2\%), Каргопольском (на 56,7\%) районах, Ненецком автономном округе (на 40,5\%); при этом в ряде регионов области заболеваемость достигла низкого уровня (ниже 10 случаев на 100000 населения), характерного для развитых стран Европы (Вилегодский район - 0 случаев на 100000 населения, Холмогорский район - 4,3 случая на 100000 населения, Виноградовский район - 6,3 случая на 100000 населения; Красноборский район - 7,6 случая на 100000 населения; Пинежский район - 7,9 случая на 100000 населения, Онежский район - 8,9 случая на 100000 населения). Существенно снизился уровень заболеваемости гонококковой инфекцией в городах Архангельске (на 20,5\%, до 102,5 случая на 100000 населения), Коряжме (на 25,9\%, до 49,3 случая на 100000 населения), Котласе (на 2,3\%, до 55,9 случая на 100000 населения), Новодвинске (на 10,9\%, до 37,6 случая на 100000 населения), Северодвинске (на 10,3\%, до 122,3 случая на 100000 населения).

Повышение уровня заболеваемости гонококковой инфекцией в 2013 г. в сравнении с 2012 г. отмечено в $6(23,1 \%)$ регионах области: Мезенском (на 36,8\%, 40,9 случая на 100000 населения), Онежском (на 53,4\%, 8,8 случая на 100000 населения), Пинежском (на 107,9\%, 7,9 случая на 100000 населения), Устьянском (на 53,6\%, 51,9 случая на 100000 населения), Шенкурском (на 2,9\%, 21,0 случая на 100000 населения), г. Мирном (на 20,2\%, 19,6 случая на 100000 населения); при этом уровень заболеваемости, превышающий средний по России, зарегистрирован только в 2 районах: Мезенском и Устьянском. Данные районы требуют пристального внимания и выяснения эпидемиологических фракторов, способствующих распространению гонококковой инфекции.

Таким образом, внедрение в практическое здравоохранение разработанного Комплекса профилактических мероприятий по предупреждению распространения гонококковой инсекции и других ИППП в Архангельской области позволило к 2013 г. существенно снизить уровень заболеваемости гонококковой инфекцией на территории области. Полученные данные позволяют положительно оценить эффективность разработанных мероприятий и отметить их вклад в снижение уровня заболеваемости гонококковой инфекцией. II 


\section{Литература}

1. Resources and activity of the medical organizations of a dermato-venereologic profile. Incidence of sexually transmitted infections, infectious skin diseases and skin diseases (Statistical materials). Moskva 2013. 220 s. [Ресурсы и деятельность медицинских организаций дерматовенерологического просиля. Заболеваемость инфекциями, передаваемыми половым путем, заразными кожными болезнями и болезнями кожи (Статистические материалы). Москва 2013; 220.]

2. Avaliable at: http://data.euro.who.int/ cisid/?TabID=309415

3. Baryshkov K.V., Prib I.D., Frigo N.V., Solomka V.S. Epidemiological aspects of incidence of a N. gonorrhoeae-infection in the Arkhangelsk region. Vestn dermatol i venerol 2013; 3: 5-17. [Барышков К.В., Приб И.Д., Фриго Н.В., Соломка В.С. Эпидемиологические аспекты заболеваемости гонококковой инфекцией в Архангельской области. Вестн дерматол и венерол 2013; (3): 5-17.]
4. Baryshkov K.V., Frigo N.V., Solomka V.S. Molecular monitoring and determination of sensitivity of $N$. gonorrhoeae to antimicrobic preparations as instruments of control over distribution of a N. gonorrhoeae-infection in the Arkhangelsk region. Vestn dermatol i venerol 2013; 4: 52—63. [Барышков К.В., Фриго Н.В., Соломка В.С. Молекулярный мониторинг и определение чувствительности N. gonorrhoeae к антимикробным препаратам как инструменты контроля над распространением гонококковой инфрекции в Архангельской области. Вестн дерматол и венерол 2013; (4): 52—63.]

5. World Health Organization. STD Treatment Strategies. Geneva: World Health Organization 1989; 30.

6. Global strategy for the prevention and control of sexually transmitted infections: 2006-2015. Key messages. Geneva, World Health Organization, 2006 (WHO/RHR/6.10) (Avaliable at: http:// whqlibdoc.who.int/hq/2006/WHO_RHR_06.10_ eng.pdf, accessed 19 March 2012).)
7. Incidence of the population of the Arkhangelsk region in 2011. Arhangel'sk MIAC 2012. 92 s. [3aболеваемость населения Архангельской области в 2011 г. Архангельск МИАЦ 2012; 92.]

8. Incidence of the population of the Arkhangelsk region in 2012. Arhangel'sk MIAC 2013. 92 s. [3aболеваемость населения Архангельской области в 2012 г. Архангельск МИАЦ 2013; 92.]

9. Activity and resources of the medical organizations of the Arkhangelsk region for 2011. Arhangel'sk MIAC 2012. 96 s. [Деятельность и ресурсы медицинских организаций Архангельской области за 2011 г. Архангельск МИАЦ 2012; 96.]

10. Activity and resources of the medical organizations of the Arkhangelsk region for 2012. Arhangel'sk MIAC 2013. 96 s. [Деятельность и ресурсы медицинских организаций Архангельской области за 2012 г. Архангельск МИАЦ 2013; 100.]

\section{об авторах:}

А.А. Кубанов - д.м.Н., профессор, зам. директора по научной работе ФГБУ «ГНЦДК» Минздрава России, Москва

К.В. Барышков - главный врач ГБУЗ АО «Архангельский клинический кожно-венерологический диспансер»

И.Д. Приб - зам. главного врача по лечебно-экспертной работе ГБУЗ АО «Архангельский клинический кожно-венерологический диспансер»

Н.В. Фриго - д.м.Н., зам. директора по научно-образовательной работе ФГБУ «ГНЦДК» Минздрава России, Москва

\section{Конфликт интересов}

Авторы заявляют об отсутствии потенциального конфлликта интересов, требующего раскрытия в данной статье 